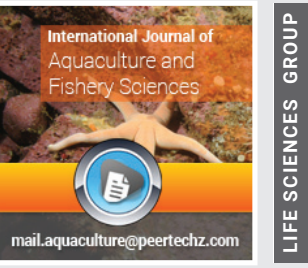

\title{
Bioremedial effect of
}

turmeric (Curcuma longa)

on haematological and

\section{biochemical parameters}

against fenvalerate induced

\section{toxicity in air-breathing fish}

\section{Clarias batrachus}

\section{Pratibha Kumari and Dilip Kumar Paul*}

Department of Zoology, Patna University, Patna, Bihar, India
Received: 26 May, 2020

Accepted: 17 June, 2020

Published: 18 June, 2020

*Corresponding author: Dr. Dilip Kumar Paul, Associate Professor, Department of Zoology, Patna University, Patna, Bihar, India, Tel: 9431421104 ;

E-mail:dkpaul@patnauniversity.ac.in

Keywords: Fenvalerate; Turmeric rhizome; Haematology; Biochemical assay

https://www. peertechz.com

\section{Check for updates}

\begin{abstract}
Indiscriminate use of insecticides has increased many folds in the recent times. Farmers for the better yield of crops, are widely utilising the pesticides. These pesticides through agricultural run offs have reached the surface water like ponds and has contaminated the flora and fauna of it. Fish is the animal which are extensively cultivated in these ponds. Humans are consuming these fishes as food as they have high nutritious value. These contaminated fish if consumed by the human has caused various health hazards to humans. The present research work is therefore focused to know the bioremedial effect of turmeric on fenvalerate induced toxicity in fish Clarias batrachus.

Fenvalerate EC $20 \%$ (pyrethroid) was administered directly in water contained in aquarium at the dose of 0.92 ppm and observed for 96 hours after the dose calculation through $\mathrm{LC}_{50}$. Thereafter, aqueous rhizome extract of Turmeric was administered orally, daily by gastric intubation method at the dose of $100 \mathrm{mg} / \mathrm{Kg}$ body weight per day for 15 days. The study reveals that after the exposure of fenvalerate, there was significant damage at the haematological and biochemical levels in fish Clarias batrachus. But, after the administration of rhizome extract of turmeric, there was significant normalisation in the haematological and biochemical levels in fish. This denotes that turmeric not only possesses ameliorating and rejuvenating property but also maintains the normal functioning of the body of the fish. Thus, it proves to be one of the best antidote against fenvalerate induced toxicity.
\end{abstract}

\section{Introduction}

The wide use of agrochemicals under conventional agriculture has caused severe health hazards for human beings. It also has caused numerous other side effects on the environment including destruction of the biodiversity. The pesticide enters aquatic ecosystems through various routes and poses a risk to many non-target aquatic organisms, particularly those inhabiting water bodies adjacent to agricultural fields. Although synthetic pyrethroids have been claimed as safe and environmentally friendly because of their selective toxicity to insects, low persistence and low toxicity to mammals and birds, they are highly toxic to a number of other non-target organisms including fish, lobster, shrimp, mayfly nymphs and many species of zooplankton. Fenvalerate is compatible with many other pesticides, plant growth regulators and micronutrients [1-3]. It causes very least impact on the mammalians but possesses very high insecticidal activity. It is known to be very potent neurotoxicant and disrupts the function of sodium channels in insects [4,5]. Furthermore, it also damages the gamma aminobutyric acid receptors [6] and ATPase pathways $[7,8]$. Indiscriminate use of fenvalerate 
pesticides in agricultural practices has resulted in accumulation in vital tissues of fish $[9,10]$. The toxicological evaluation of fenvalerate has been carried out by various researchers [11-13].

In the recent years, the Indian System of Health Practice Ayurveda has attracted use of medicinal plants as antidote for various types of drug and chemical toxicity [14].

Most of the studies demonstrate the promising potential of medicinal plants used in various traditional, complementary and alternate systems of treatment of human diseases. Curcuma longa (turmeric), belongs to Zingiberacea family and is found in tropical South Asia. Turmeric is widely used in food, cosmetics and pharmaceutical industries. There are about 100 active compounds found in this herb but curcumin is the major active ingredient [15]. It has different biological activities such as antioxidant [16], anti-carcinogenic [17,18] and antiinflammatory activity $[19,20]$.

The objective of the present investigation is to ascertain the toxic impact of Fenvalerate a most commonly used insecticide on haematological and biochemical parameters of an air breathing fish Clarias batrachus and bioremedial property of a medicinal plant, Turmeric (Curcuma longa L.) in order to generate data for medicinal use of Turmeric as detoxifying and antioxidant agent.

\section{Materials and methods}

\section{Animals}

Live specimens of air breathing fish Clarias batrachus were procured from the local market of Patna, Bihar (India) and were acclimatized in laboratory before experimentation. The laboratory room temperature was maintained to $24 \pm 2$ degree centigrade. The fishes were kept in big aquaria (50 gallon capacity). The animals were fed with chopped goat liver and earthworms. Care was taken to keep the animals healthy and free from parasites. The experiment was established in the Department of Zoology, Patna University, Patna, Bihar, India. The ethical approval was obtained from the Post Graduate Research Council of Patna University, Patna, Bihar.

\section{Test chemical}

Fenvalerate $20 \%$ (Isagro-Asia, Gujarat, India) was administered directly in water contained in aquarium at the dose of $0.92 \mathrm{ppm}$ and observed after 96hrs after the dose calculation through $\mathrm{LC}_{50}(2.75 \mathrm{ppm})$.

\section{Preparation of turmeric rhizome dose}

In the present study, Turmeric rhizome were collected from the local market of Patna and aqueous extract of Turmeric rhizome was made to the dose of $100 \mathrm{mg} / \mathrm{Kg}$ body weight per day after the $\mathrm{LD}_{50}$ estimation (700 $\mathrm{mg} / \mathrm{Kg}$ body weight). The aqueous extract of Turmeric was administered orally, daily by gastric intubation method to the fish.

\section{Study groups \& sampling}

The control group of fish received no treatment. The 'treatment' groups received fenvalerate at the dose of $0.92 \mathrm{ppm}$ and observed for $96 \mathrm{hrs}$ in the aquariums and were sacrificed thereafter. The third aquarium fishes were first treated with fenvalerate insecticide at the dose of $0.92 \mathrm{ppm}$ and observed for $96 \mathrm{hrs}$ then after were administered with Turmeric aqueous extract at the dose of $100 \mathrm{mg} / \mathrm{Kg}$ body weight per day orally, daily by gastric intubation method to the fish for 15 days.

\section{Haematological evaluation}

The haematological parameters Red Blood Cell Count (RBC's), Total Leukocyte Count, Packed Cell Volume (PCV), Haemoglobin percentage (HGB),) and Differential counts (DLC) - Eosinophil, Lymphocytes and Monocytes were done manually.

\section{Biochemical evaluation}

For biochemical study, serum from the fish blood was extracted and tests were carried out. In this study, the total glucose levels, total protein levels and total cholesterol levels were evaluated.

\section{Statistical analysis}

Results are presented as mean \pm SD and total variation present in a set of data was analysed through one-way analysis of variance (ANOVA). Difference among mean values has been analysed by applying Dunnett's test. Calculations were performed with the Graph Pad Prism Program (Graph Pad software, Inc., San Diego, U.S.A.). The criterion for statistical significance was set at $P<0.05$.

\section{Results}

Haematological Evaluation: In the haematological study, there was significant decrease in the RBC counts, TLC counts, differential counts, PCV percentage, haemoglobin percentage, PCV, neutrophils, eosinophils and monocyte levels after Fenvalerate exposure while after Turmeric treatment there was significant restoration in their levels. But, in Lymphocytes percentage there was significant increase after the fenvalerate treatment but there was gradual decrease in the percentage after the turmeric treated for 15 days (Table 1).

\section{Biochemical evaluation}

In the present study, there was significant increase in the levels of serum glucose and serum cholesterol levels while significant decrease in the levels of serum total protein levels in Fenvalerate treated group in comparison to control. But, after the treatment of turmeric for 15 days, there was significant decrease in the serum glucose and cholesterol levels while significant increase in the serum plasma levels in comparison to the control group (Table 2 and Figures 1-3).

\section{Discussion}

Environmental problems in the recent times has increased many folds. The technological development has improved the quality of life while on the other hand it has created serious health hazards to the humans. The indiscriminate use of pesticides in agricultural practices has increased the pollution 
level at much extent. The impact of pesticides on aquatic system is due to the migration of pesticides from various diffuse or point sources. This has led to cause threat to the aquatic life especially the fishes. The biomagnification of these pesticides in the aquatic life has posed serious threats to them. Humans are consuming the fish as one of the major sources of protein in their diet. But, if there is threat of poisoning of the fish through the pesticides, then it will cause severe entry of toxicants in the human system [21,22].

The fish act as bio-indicator of water quality and the impact of the pesticide can be well understood by analyzing either blood or serum of the fish, because blood is a pathophysiological reflector of whole body $[23,24]$.

Table 1: Mean haematological parameters of Clarias batrachus exposed to sub lethal concentration of Fenvalerate (0.92ppm) for $96 \mathrm{hrs}$ and amelioration by turmeric

\begin{tabular}{|c|c|c|c|}
\hline Parameters & Control & $\begin{array}{c}\text { Fenvalerate Treated } \\
\text { for } 96 \text { hours }\end{array}$ & $\begin{array}{c}\text { Turmeric } \\
\text { Treated for 15 } \\
\text { days }\end{array}$ \\
\hline RBC $\left(\times 10^{6} \mathrm{~mm}^{-3}\right)$ & $2.76 \pm 0.032$ & $2.14 \pm 0.023$ & $2.62 \pm 0.012$ \\
\hline $\begin{array}{c}\text { Total Leukocyte Count } \\
\left(\times 10^{3} \mathrm{~m}^{-3}\right)\end{array}$ & $18.10 \pm 0.015$ & $16.30 \pm 0.074$ & $17.95 \pm 0.030$ \\
\hline $\begin{array}{c}\text { Differential Count } \\
\left(\mathrm{x} 10^{6} \mathrm{~mm}^{-3}\right)\end{array}$ & $12 \pm 0.230$ & $09 \pm 0.083$ & $12 \pm 0.364$ \\
\hline Packed Cell Volume (\%) & $24 \pm 0.189$ & $16 \pm 0.041$ & $23 \pm 0.174$ \\
\hline Haemoglobin (g/100ml) & $6.89 \pm 0.031$ & $4.23 \pm 0.073$ & $6.37 \pm 0.309$ \\
\hline Neutrophils (\%) & $21.70 \pm 0.085$ & $42.60 \pm 0.253$ & $26.12 \pm 0.782$ \\
\hline Eosinophils (\%) & $78 \pm 0.027$ & $64 \pm 0.061$ & $76 \pm 0.0201$ \\
\hline Lymphocytes (\%) & $10 \pm 0.152$ & $16 \pm 0.091$ & $10 \pm 0.152$ \\
\hline Monocytes (\%) & $01 \pm 0.039$ & 0 & $0.7 \pm 0.499$ \\
\hline
\end{tabular}

Data are presented as SEM with $P<0.05$

Table 2: Mean biochemical parameters of Clarias batrachus exposed to sub lethal concentration of Fenvalerate (0.92ppm) for $96 \mathrm{hrs}$ and amelioration by turmeric.

\begin{tabular}{|c|c|c|c|}
\hline Parameters & Control & $\begin{array}{c}\text { Fenvalerate Treated } \\
\text { for } \mathbf{9 6} \text { hours }\end{array}$ & $\begin{array}{c}\text { Turmeric Treated for } \\
\mathbf{1 5} \text { days }\end{array}$ \\
\hline $\begin{array}{c}\text { Serum Glucose Levels } \\
(\mathrm{mg} / \mathrm{dl})\end{array}$ & $50.31 \pm 5.811$ & $103.8 \pm 4.336$ & $51.51 \pm 4.519$ \\
\hline $\begin{array}{c}\text { Serum Cholesterol } \\
\text { Levels }(\mathrm{mg} / \mathrm{dl})\end{array}$ & $169.4 \pm 11.84$ & $248.6 \pm 17.58$ & $167.6 \pm 6.844$ \\
\hline $\begin{array}{c}\text { Serum Total Protein } \\
\text { Levels }(\mathrm{mg} / \mathrm{dl})\end{array}$ & $3.150 \pm 0.112$ & $2.577 \pm 0.167$ & $3.103 \pm 0.092$ \\
\hline
\end{tabular}

Data are presented as SEM with $P<0.05$

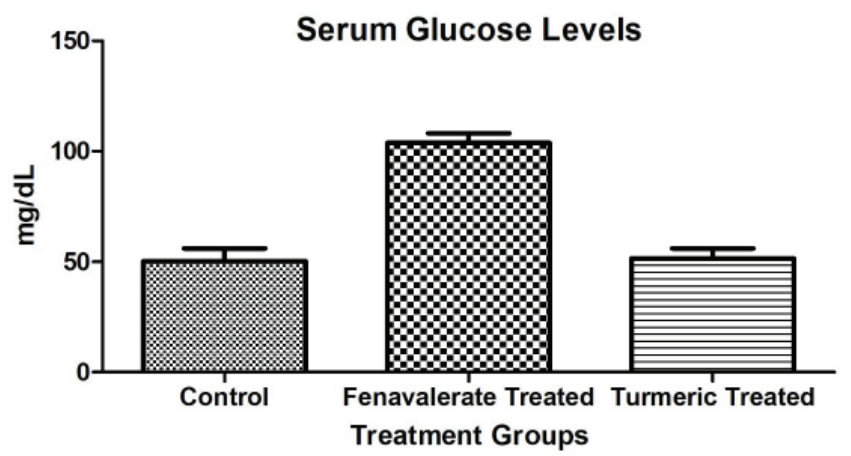

Figure 1: Effect of Turmeric on Fenvalerate induced toxicity showing Serum Glucose levels $(n=6$, values are mean \pm S.D)

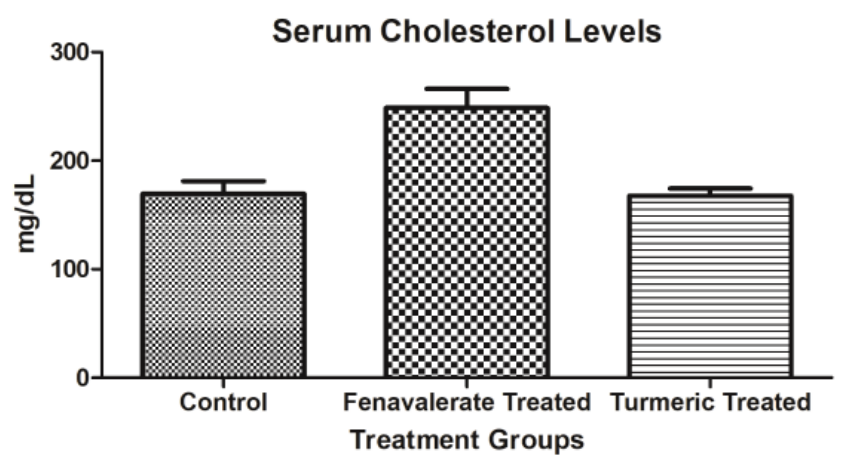

Figure 2: Effect of Turmeric on Fenvalerate induced toxicity showing Serum Cholesterol levels $(n=6$, values are mean \pm S.D)

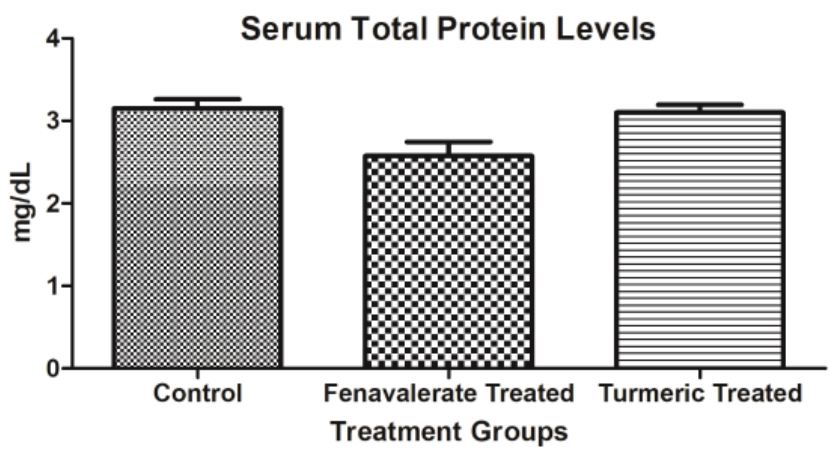

Figure 3: Effect of Turmeric on Fenvalerate induced toxicity showing Serum total Protein levels $(n=6$, values are mean \pm S.D)

Haematological study is an important parameter in the evaluation of toxicity in the aquatic animals. A thin epithelial membrane separates fish blood from the water and any significant change in the water body are reflected in the blood parameters [25]. In the present study, in the haematological study there was significant decrease in the RBC counts, TLC counts, Differential counts, haemoglobin percentage, PCV percentage, neutrophils, Eosinophils and monocytes percentage after Fenvalerate exposure while after Turmeric treatment there was significant decrease in their levels. There was significant increase in the Lymphocyte percentage after Fenvalerate exposure but in Turmeric treated group there was significant decrease in their levels.

This effect of Fenvalerate on Clarias batrachus might have been through failure or suppression of normal mechanisms promoting erythropoiesis or deficiency of some factors required for the maturation of the red cell. The causes of leucopenia observed in the present study are supposed to be according to the degeneration, depression, depletion and destruction of the blood forming materials by these compounds. The observed depletion in the haemoglobin percentage in the fish could also be attributed to the lysis of erythrocytes. Thus, the significant reduction in these parameters is an indication of severe anaemia [26-28].

The white blood cells in fish respond to various stressors including infections and chemical irritants. Thus, increasing or decreasing numbers of white blood cells are a normal reaction on the exposure of toxicants. In the present investigation,

Citation: Kumari P, Paul DK (2020) Bioremedial effect of turmeric (Curcuma longa) on haematological and biochemical parameters against fenvalerate induced toxicity in air-breathing fish Clarias batrachus. Int J Aquac Fish Sci 6(2): 056-060. DOI: https://dx.doi.0rg/10.17352/2455-8400.000057 
there was gradual decrease in the WBC counts as leucocytosis may have resulted due to the breach in the defence mechanism which resulted in the increased levels. A sharp increase was observed in the lymphocytes percentage denotes that the magnitude of toxicity was very high [29].

In the present study, there was significant increase in the biochemical parameters in serum glucose levels and serum cholesterol levels while decrease in the serum total protein levels. This denotes that pesticides are severely accumulated in the fat tissue of the fish disrupting the glucose biomarkers of the fish. On the other hand, the fish are the major source of rich proteins but due to the pesticide toxicity there is significant loss protein content as it is clearly reflected the serum total protein levels [30,31].

In the present study, the Turmeric was used as antidote against the Fenvalerate induced toxicity in Clarias batrachus. There was significant increase in the haematological parameters RBC counts, Total leucocyte counts, Differential counts, Packed cell volume percentage, haemoglobin percentage, neutrophil percentage, Eosinophil percentage and Monocyte percentage while decrease in the Lymphocyte percentage against Fenvalerate induced toxicity. This denotes that the haematopoietic stem cells are significantly revived due antioxidant activity of Curcumin. Moreover, the defence mechanism in the fish has enhanced many folds due to the defence activity of curcumin [32,33]. Curcumin possesses dual antioxidant activity and acts through the scavenging reactive oxygen species (ROS) including superoxide and hydroxyl radicals due to its phenolic structure, and induces the upregulation of several endogenous cytoprotective and antioxidant proteins. It is also an effective lipid peroxidation inhibitor $[34,35]$.

In the present study, there was significant normalisation in the biochemical parameters - serum glucose levels, serum cholesterol levels and total protein levels after turmeric treatment. The antioxidant activity and the protective effect of curcumin has played the major role to control the Fenvalerate induced toxicity $[32,36-41]$.

The study denotes that Turmeric possesses antidote and antitoxic effect against Fenvalerate induced toxicity in Clarias batrachus.

\section{Conclusions}

Fenvalerate causes severe damage to the fish at haematological and biochemical level. But, turmeric plays the vital role in combating the deleterious effects of Fenvalerate induced toxicity thus possesses the antidote and bioremedial activity.

\section{Acknowledgements}

The authors extend their appreciation to the Department of Zoology, Patna University, Patna for providing the entire logistics for the practical work.

\section{References}

1. Tomlin C (1995) The pesticide manual. Tenth Edition. Crop protection Publications. Bath Press Bath UK 1341

2. Elbert A, Brück E, Melgarejo J, Schnorbach HJ, Sone S (2005) Field develop ment of Oberon for whitefly and mite control in vegetables, cotton, corn, strawberries, ornamentals and tea. Pflanzenschutz-Nachrichten Bayer 58: 441-468.

3. Bretschneider T, Fischer R, Nauen R (2007) Inhibitors of lipid synthesis. In Modern Crop Protection Compounds, Vol. 3 (Krämer W. and Schirmer U., eds.) WILEY-VCH GmbH \& Co. KGaA, Weinheim, Germany 909-925.

4. Narahasi T (1983) Nerve membrane sodium channels as the major target site of pyrethroids and DDT. In: Miyamoto, J., Kearney, P.C. (Eds.), Mode of Action, Metabolism and Toxicology. Pesticide Chemistry: Human Welfare and the Environment. Pergamon Press, New York 3: 109-114. Link: https://bit.ly/2YJCOKF

5. Eells JT, Rasmussen JL, Bandettini PA, Propp JM (1993) Differences in the neuroexcitatory action of pyrethroid insecticides and sodium channel-specific neurotoxins in rat and trout brain synaptosomes. Toxicol Appl Pharmacol 123 107-119. Link: https://bit.ly/37EhVoA

6. Cole LM, Lawerence LJ, Casida JE (1984) Similar properties of 35S-tbutylbicyclophosphorothloate receptor and coupled component of the GABA receptor - ionophore complex in brains of human, cow, rat, chicken and fish. Life Sci 35: 1755- 1762. Link: https://bit.ly/2Bb1nYZ

7. Clark JM, Matsumura F (1982) Two different types of inhibitory effect of pyrethroids on nerve $\mathrm{Ca} 2+-$ and $\mathrm{Ca} 2+-\mathrm{Mg} 2+-$ ATPase activity in the squid Loligo pealei. Pestic Biochem Physiol 18: 180-190. Link: https://bit.ly/2Y7gGLa

8. Matsumura F (1983) Influence of chlorinated and pyrethroid insecticides on cellular calcium regulatory mechanisms. In: Miyamoto, J., Kearney, P.C. (Eds.) Mode of Action, Metabolism and Toxicology. Pesticide Chemistry: Human Welfare and the Environment 3- 13. Link: https://bit.ly/3eagJeX

9. Coats JR, Symonik DM, Braduary SP, Dyer SD, Tinson LK, et al. (1989) Toxicology of synthetic pyrethroids in aquatic organisms. An overview. Environ Toxicol Chem 8: 671- 679. Link: https://bit.ly/2BcyziW

10. Mishra S (1996) Bioaccumulation, biotoxicity and biodegradation of fenvalerate in rats. PhD thesis, University of Roorkee, India.

11. Lee PW, Stearns SM, Powell WR (1985) Rat metabolism of fenvalerate (Pydrin insecticide). J Agric Food Chem 33: 988-993. Link: https://bit.ly/3hAG8Az

12. Tripathi G (1992) Relative toxicity of aldrin, fenvalerate, captan and diazinon to the freshwater food-fish, Clarias batrachus. Biomed Environ Sci 5: 33-38. Link: https://bit.ly/2zCGt4u

13. Tripathi G, Verma $P$ (2004) Fenvalerate-induced changes in a catfish, Clarias batrachus: metabolic enzymes, RNA and protein. Comp Biochem Physiol C Toxicol Pharmacol 138: 75-79. Link: https://bit.ly/2Y9Z7tX

14. Datta-Mitra A, Ahmed O (2014) Ayurvedic medicine use and lead poisoning in a child: A continued concern in the United States. Clin Pediatr (Phila) 89: 1141 Link: https://bit.ly/2UR7HvO

15. Ruby A, Kuttan G, Babu KD, Rajasekharan K, Kuttan R (1995) Anti-tumour and antioxidant activity of natural curcuminoids. Cancer Lett 94: 79-83. Link: https://bit.ly/2Cg6Z40

16. Tuba Ak, Gülçin I (2008) Antioxidant and radical scavenging properties of curcumin. Chem Biol Interact 174: 27-37. Link: https://bit.ly/3dboj7Q

17. Shukla Y, Arora A, Taneja P (2002) Antimutagenic potential of curcumin on chromosomal aberrations in Wistar rats. Mutat Res 515: 197-202. Link: https://bit.ly/2YOQOTM

Citation: Kumari P, Paul DK (2020) Bioremedial effect of turmeric (Curcuma longa) on haematological and biochemical parameters against fenvalerate induced toxicity in air-breathing fish Clarias batrachus. Int J Aquac Fish Sci 6(2): 056-060. DOI: https://dx.doi.0rg/10.17352/2455-8400.000057 
18. Sahebkar A (2016) Curcumin: A natural multitarget treatment for pancreatic cancer. Integr Cancer Ther 15: 333-334. Link: https://bit.ly/2YdNwud

19. Jurenka JS (2009) Anti-inflammatory properties of curcumin, a major constituent of Curcuma longa: a review of preclinical and clinical research. Altern Med Rev 14: 141-153. Link: https://bit.ly/3fy6SzY

20. Panahi Y, Hosseini MS, Khalili N, Naimi E, Majeed M, et al. (2015) Antioxidant and anti-inflammatory effects of curcuminoid-piperine combination in subjects with metabolic syndrome: a randomized controlled trial and an updated metaanalysis. Clin Nutr 34: 1101-1108. Link: https://bit.ly/3fAyEfg

21. Clasen B, Loro VL, Murussi CR, Tiecher TL, Moraes B, et al. (2018) Bioaccumulation and oxidative stress caused by pesticides in Cyprinus carpio reared in a rice-fish system. Sci Total Environ 626: 737-743. Link: https://bit.ly/2Cjq5qR

22. Yang C, Lim W, Song G (2020) Mediation of oxidative stress toxicity induced by pyrethroid pesticides in fish. Comp Biochem Physiol C Toxicol Pharmacol 234: 108758. Link: https://bit.ly/2N2K1jP

23. Sharma G, Singh S (2006) Assay of some blood parameters of the fish, Channa punctatus (Bloch.) after intoxication of indofil. Bionotes 8: 21.

24. Sharma G, Singh S (2004) Studies on the effect of intoxicant indofil on the blood morphology of Channa punctatus (Bloch). Bionotes 6: 20

25. Bojarski B, Witeska M (2020) Blood biomarkers of herbicide, insecticide, and fungicide toxicity to fish-a review. Environ Sci Pollut Res Int 27: 19236-19250. Link: https://bit.ly/2CgIK7G

26. Abd El-Rahman GI, Ahmed SAA, Khalil AA, Abd-Elhakim YM (2019) Assessment of hematological, hepato-renal, antioxidant, and hormonal responses of Clarias gariepinus exposed to sub-lethal concentrations of oxyfluorfen. Aquat Toxicol 217: 105329. Link: https://bit.ly/2N3y6lx

27. Narra MR, Rajender K, Reddy RR, Murty US, Begum G (2017) Insecticides induced stress response and recuperation in fish: Biomarkers in blood and tissues related to oxidative damage. Chemosphere 168: 350-357. Link: https://bit.ly/2C903Va

28. Narra MR (2016) Single and cartel effect of pesticides on biochemical and haematological status of Clarias batrachus: A long-term monitoring. Chemosphere 144: 966-974. Link: https://bit.ly/2AJOEhN

29. Gül A, Benli AÇ, Ayhan A, Memmi BK, Selvi M, et al. (2012) Sublethal propoxur toxicity to juvenile common carp (Cyprinus carpio L., 1758): biochemical, haematological, histopathological, and genotoxicity effects. Environ Toxicol Chem 31: 2085-2092. Link: https://bit.ly/2AIZKIs

30. Binukumari S, Devi KA, Vasanthi J (2016) Applications in environmental risk assessment of biochemical analysis on the Indian fresh water fish, Labeo rohita exposed to monocrotophos pesticide. Environ Toxicol Pharmacol 47 200-205. Link: https://bit.ly/2YMFO98

31. Vieira CED, Dos Reis Martinez CB (2018) The pyrethroid $\lambda$-cyhalothrin induces biochemical, genotoxic, and physiological alterations in the teleost Prochilodus lineatus. Chemosphere 210: 958-967. Link: https://bit.ly/2UPIj9u

32. Xu XY, Meng X, Li S, Gan RY, Li Y, et al. (2018) Bioactivity, Health Benefits, and Related Molecular Mechanisms of Curcumin: Current Progress, Challenges, and Perspectives. Nutrients 10: 1553. Link: https://bit.ly/2USROor

33. Mişe Yonar S, Yonar ME, Ural MS (2017) Antioxidant effect of curcumin against exposure to malathion in Cyprinus carpio. Cell Mol Biol 63: 68-72. Link: https://bit.ly/2BgeOlH

34. Bami E, Ozakpınar OB, Ozdemir-Kumral ZN, Köroglu K, Ercan F, et al. (2017) Protective effect of ferulic acid on cisplatin induced nephrotoxicity in rats Environ Toxicol Pharmacol 54: 105-111. Link: https://bit.ly/3ebEmUi
35. Tvrdá E, Tušimová E, Kováčik A, Paál D, Greifová H, et al. (2016) Curcumin has protective and antioxidant properties on bull spermatozoa subjected to induced oxidative stress. Anim Reprod Sci 172: 10-20. Link: https://bit.ly/2zDVnre

36. Jiang J, Wu XY, Zhou XQ, Feng L, Liu Y, et al. (2016) Effects of dietary curcumin supplementation on growth performance, intestinal digestive enzyme activities and antioxidant capacity of crucian carp Carassius auratus. Aquaculture 463 174-180. Link: https://bit.ly/3de1CQ9

37. Mahmoud HK, Al-Sagheer AA, Reda FM, Mahgoub SA, Ayyata MS (2017) Dietary curcumin supplement influence on growth, immunity, antioxidant status, and resistance to Aeromonas hydrophila in Oreochromis niloticus. Aquaculture 475: 16-23. Link: https://bit.ly/2YGXX8t

38. Manju M, Akbarsha MA, Oommen OV (2012) In vivo protective effect of dietary curcumin in fish Anabas testudineus (Bloch). Fish Physiol Biochem 38: 309318. Link: https://bit.ly/37ApH2u

39. Mişe Yonar S, Yonar ME, Yöntürk Y, Pala A (2013) The effect of curcimin on some haematological parameters in rainbow trout (Oncorhynchus mykiss, Walbaum, 1792). BIBAD - Res J Biol Sci 1: 59-61. Link: https://bit.ly/30NEp4Y

40. Mişe Yonar S, Yonar ME, Yöntürk Y (2014b) The effect of curcumin on some antioxidant parameters in rainbow trout (Oncorhynchus mykiss Walbaum, 1792). Firat Univ J Sci 26: 53-57.

41. Yonar ME (2018) Chlorpyrifos-induced biochemical changes in Cyprinus carpio: Ameliorative effect of curcumin. Ecotoxicol Environ Saf 151: 49-54 Link: https://bit.ly/2YJUJ48

Discover a bigger Impact and Visibility of your article publication with

Peertechz Publications

\section{Highlights}

* Signatory publisher of ORCID

* Signatory Publisher of DORA (San Francisco Declaration on Research Assessment)

- Articles archived in worlds' renowned service providers such as Portico, CNKI, AGRIS, TDNet, Base (Bielefeld University Library), CrossRef, Scilit, J-Gate etc.

- Journals indexed in ICMJE, SHERPA/ROMEO, Google Scholar etc.

* OAI-PMH (Open Archives Initiative Protocol for Metadata Harvesting)

* Dedicated Editorial Board for every journal

* Accurate and rapid peer-review process

* Increased citations of published articles through promotions

* Reduced timeline for article publication

Submit your articles and experience a new surge in publication services (https://www.peertechz.com/submission).

Copyright: @ 2020 Kumari P, et al. This is an open-access article distributed under the terms of the Creative Commons Attribution License, which permits unrestricted use, distribution, and reproduction in any medium, provided the original author and source are credited.

Citation: Kumari P, Paul DK (2020) Bioremedial effect of turmeric (Curcuma longa) on haematological and biochemical parameters against fenvalerate induced toxicity in air-breathing fish Clarias batrachus. Int J Aquac Fish Sci 6(2): 056-060. DOI: https://dx.doi.0rg/10.17352/2455-8400.000057 